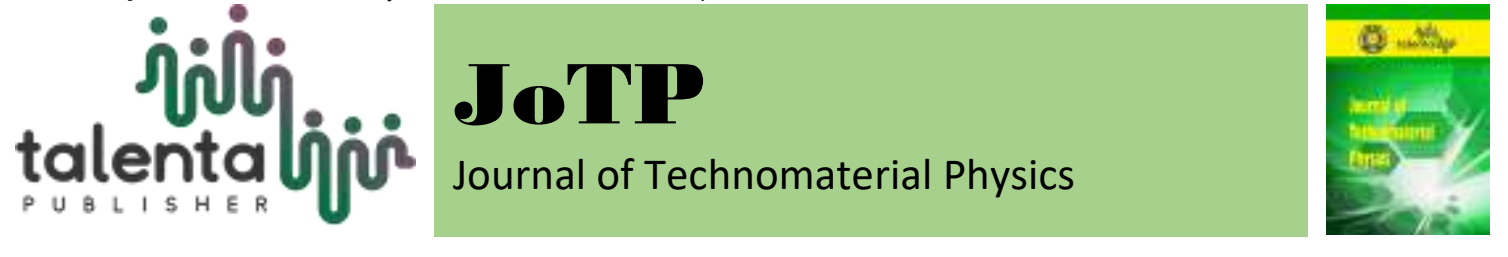

\title{
Rain Measurement Simulation Using the Hall Effect Flow-Meter
}

\author{
Bernadus Herdi Sirenden $^{1^{*}}$, Takdir Tamba ${ }^{2}$ and Elbert Setiawan Zebua ${ }^{3}$ \\ ${ }^{I}$ Physics Research Center - Indonesian Institute of Sciences (LIPI), PUSPIPTEK Region, South \\ Tangerang, Indonesia 15314 \\ ${ }^{2,3}$ Department of Physics, Faculty of Mathematics and Natural Science, Universitas Sumatera Utara, \\ Medan 20155, Indonesia
}

\begin{abstract}
The sensor analysis or flow-meter measuring instrument has been successfully carried out on the signal output to see the stability or accuracy of a measurement. The flowmeter measurement value was analyzed using a rainfall simulator. The rainfall intensity value will then be predicted using the Kalman filter. Kalman filters can predict various data or output signals so that the measurement results can be more stable and accurate. This research methodology consists of several stages, namely the stages of literature study, designing research tools and components, designing systems, making or assembling tools, testing all components, programs and testing the flow-meter output signal record. The flowmeter is controlled by the Arduino Nano microcontroller. Tests were carried out in this study ten times, with a time span of 60 seconds for each experiment. The increase in water flow was detected by the flow-meter which was then captured by the hercules application and the data was then copied to Ms. Excel. After the rainfall intensity value is obtained, the value will be estimated using the Kalman filter. The estimation results will show the stability and accuracy value of the flow-meter.
\end{abstract}

Keyword: flow-meter, Kalman filter, rainfall intensity, Arduino Nano.

Received 01 July 2020 | Revised [15 July 2020] | Accepted [27 August 2020]

\section{Introduction}

Rain is a phenomenon that often occurs in various parts of the world, especially in tropical climates such as Indonesia. Rain is a perspective in the form of liquid, different from other perspectives such as snow. One of the elements of rain that can be measured is rainfall. Rainfall is the amount of rainwater that falls on the surface per unit area $\left(\mathrm{m}^{2}\right)$. With the accuracy of measurement, the community can take solutions based on existing data. Testing the accuracy of the measurement results requires some equipment that can test the accuracy of the value or quantity. Rainfall estimators generally measure the total amount of rainfall. Several rain measurement tools using a variety of methods have been developed. The measurement value generated in the process requires accuracy [1-3].

\footnotetext{
*Corresponding author at: Physics Research Center - Indonesian Institute of Sciences (LIPI), PUSPIPTEK Region, South Tangerang, Indonesia 15314

E-mail address: bern001@lipi.go.id
} 
A flow-meter is one of the signals needed to measure the flow of material (liquid, gas) in a flow path, for example, the flow-rate, and the total mass or volume of material flowing in a certain period of time called totalizer. The flow-meter output can be a number or an electrical signal that is used as an input value for a control system. The signal or flow-meter output is affected by various signal disturbances that cause instability in the measurement which is called noise [4].

This noise can be removed by using a Kalman filter. Kalman filter is a mathematical equation that can reduce the noise in the flow-meter signal output. Kalman filter can directly show the actual data and also shows how big the error occurred in the estimated data [5-7].

\section{Methods}

In this study, the tools and materials used for flow-meter characterization in the rainfall intensity simulator are computer equipment, buckets, showers, pipe glue, storage pipes, electric solder, tin, hoses, tie ropes, connecting cables, water taps, and software of Hercules. While the materials used are the ESP32 CAM Microcontroller, Arduino IDE (Integrated Development Environment), Python software, jumper cables, USB connector and water as a source of rainfall. The tool is designed to be able to record rainfall data in one minute. In the data collection process, ten experiments were carried out. Then the data is recorded by the Hercules software and this data will be processed through a microcontroller [8-10]. Furthermore, the data is sent to Excel to view and access stored and ongoing data using Hercules software on a computer device.

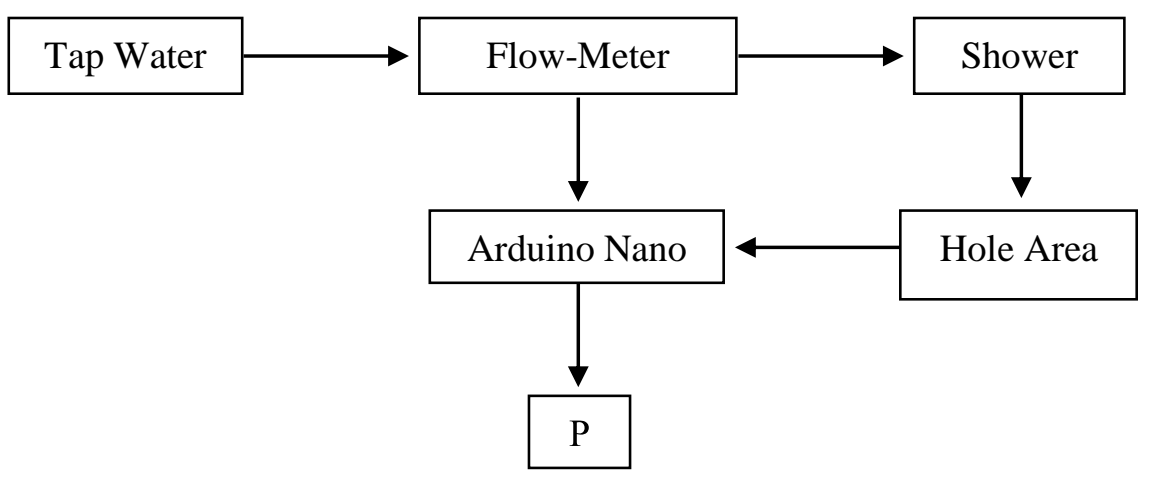

Figure 1. Block Diagram 


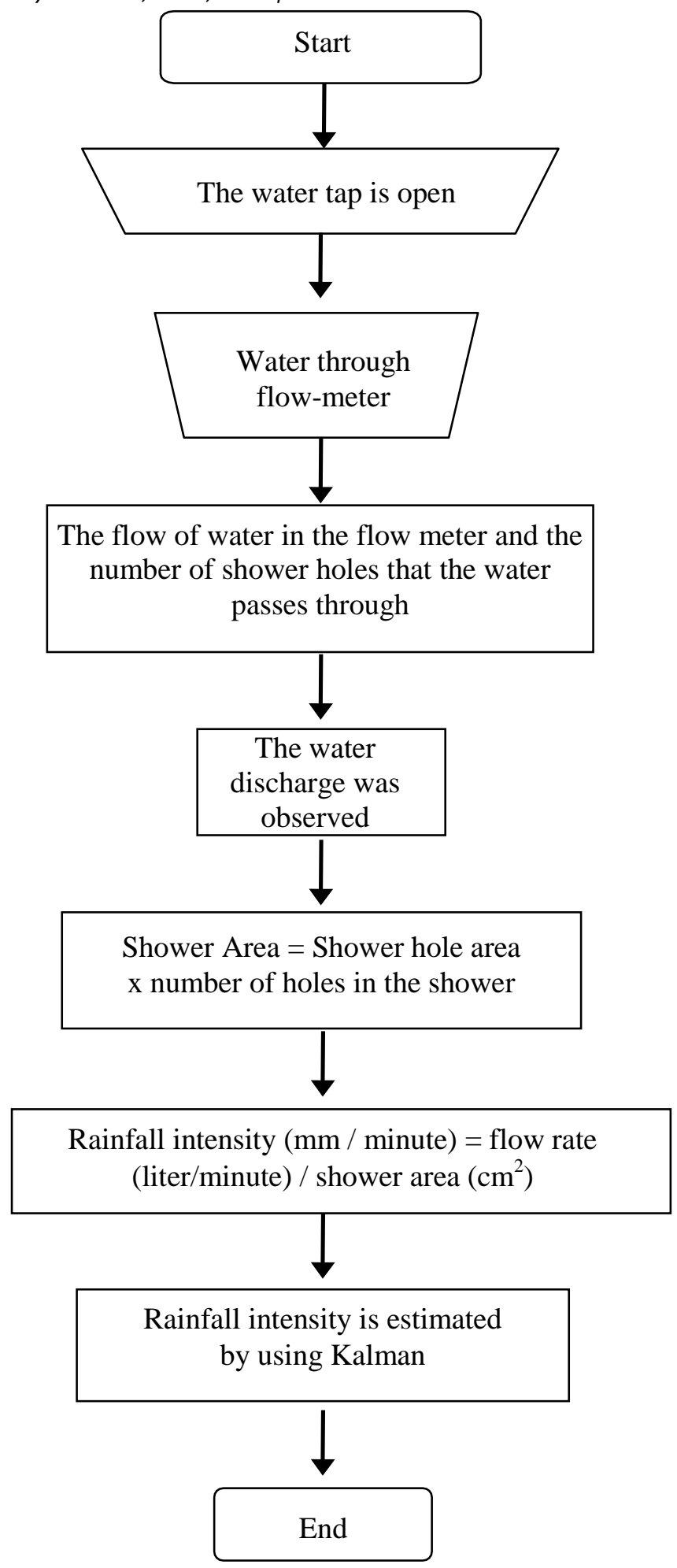

Figure 2. Flowchart

\section{Result and Discussion}

The experimental data is taken from the flow-meter output signal in the form of numerical data. This number data is the value of the water flow through the flow-meter. The data shows the value of rainfall intensity by paying attention to the value of water discharge and other parameters. Kalman Filter is used to estimate a value in the tracking system. In general, Kalman 
filters have two stages in the mathematical process. The first is the prediction of the initial value, and the correction or measurement process. The prediction process is given as follows:

$$
\begin{gathered}
X_{k}^{p}=X_{K-1}^{c} \\
Q_{K}^{0}=Q_{K-1}^{P}+T_{K-1}
\end{gathered}
$$

This prediction stage will be carried out continuously, where the value will always change. In the correction process, we must determine the gain value, where to determine the gain calman value we must first assume the uncertainty process value.

$$
\begin{gathered}
K G=Q_{K}^{0} /\left(Q_{K}^{0}+E_{\text {meea }}\right) \\
X_{K}^{C}=X_{K}^{P}+K G\left(A_{K}-X_{K}^{P}\right) \\
Q_{H}^{C}=(1-K G) Q_{K}^{0} \\
\text { Rainfall Intensity }(\mathrm{mm} / \text { minute })=\frac{\text { flow rate }(\text { liter } / \text { minute })}{\text { shower area }\left(\mathrm{cm}^{2}\right)}
\end{gathered}
$$

with

$$
\text { Shower Area }=\text { Shower hole area } x \text { number of holes }
$$

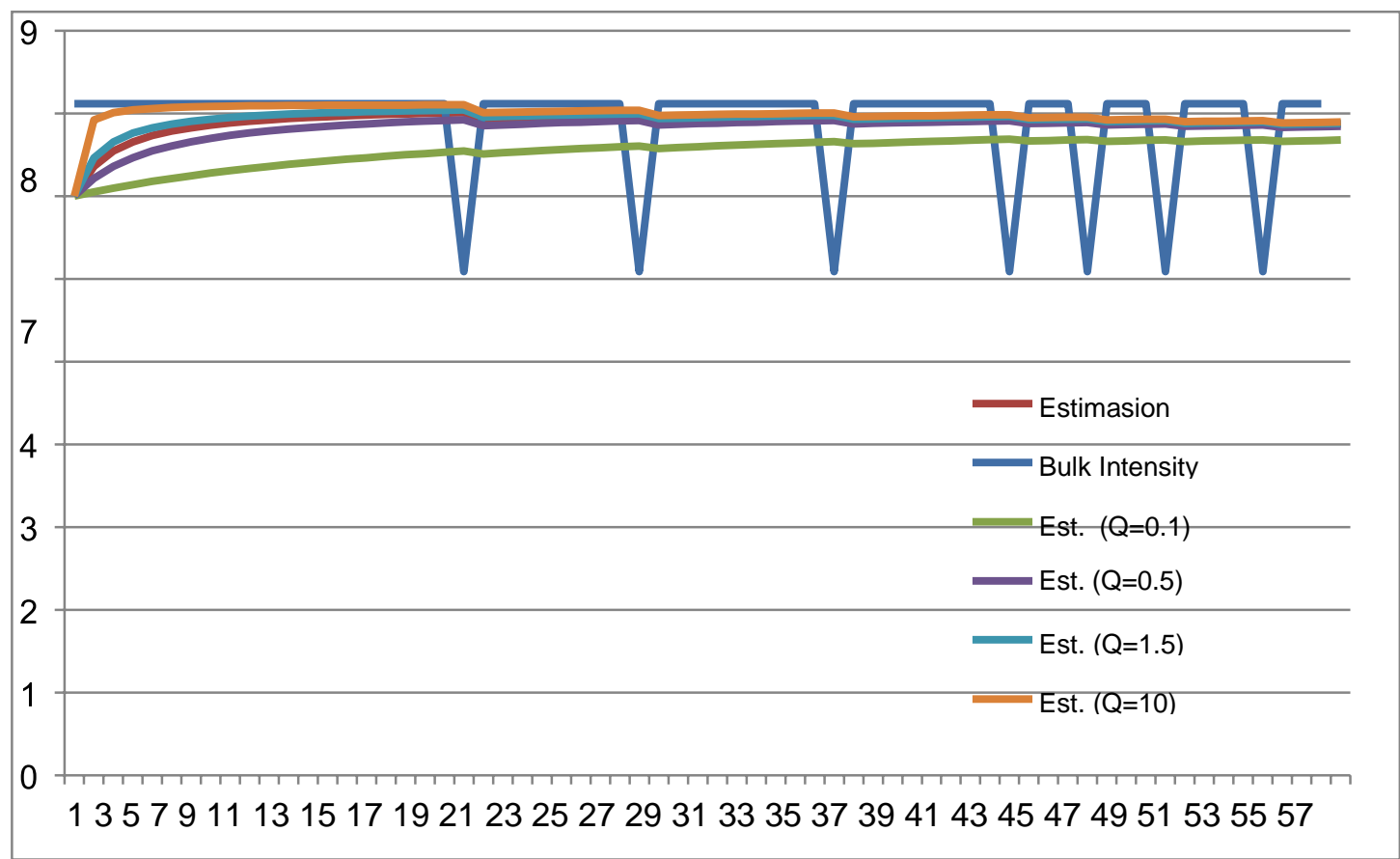

Figure 3. Comparison graph on data 1 


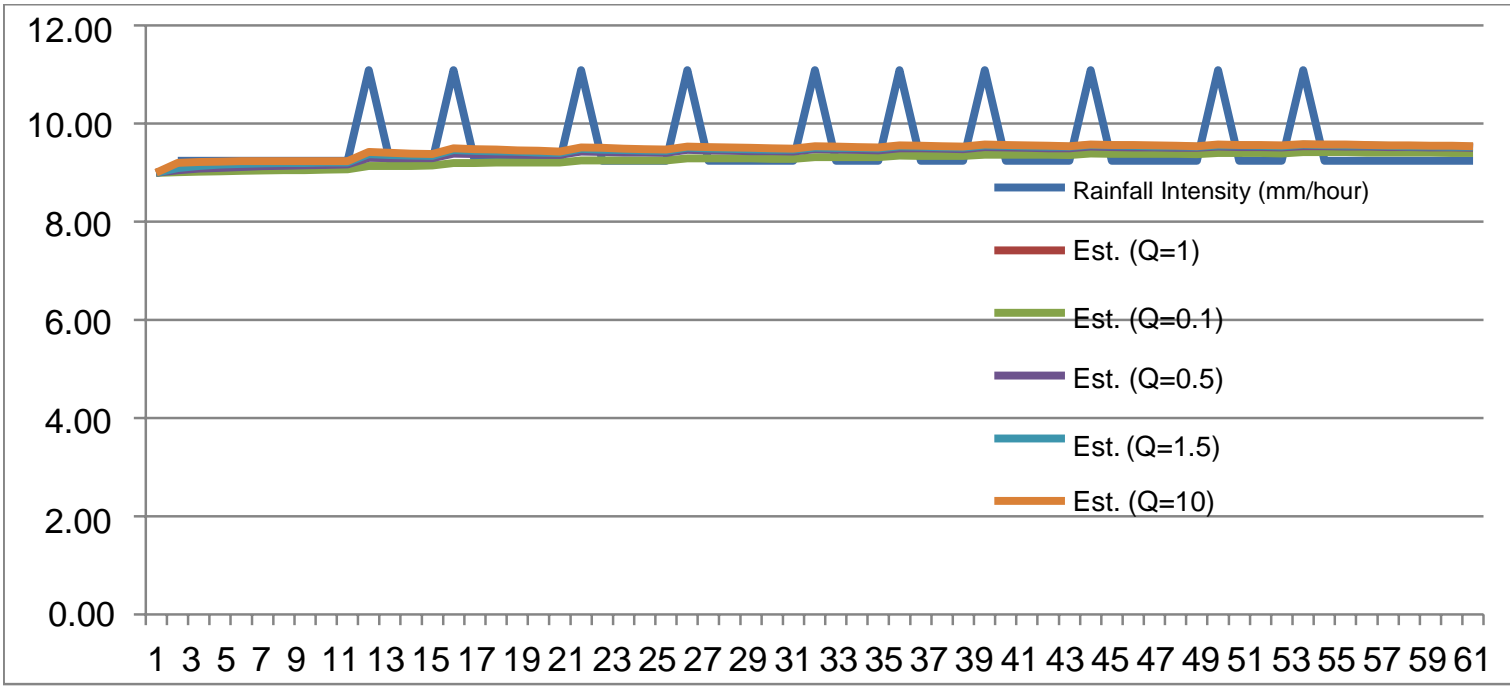

Figure 4. Comparison graph on data 2

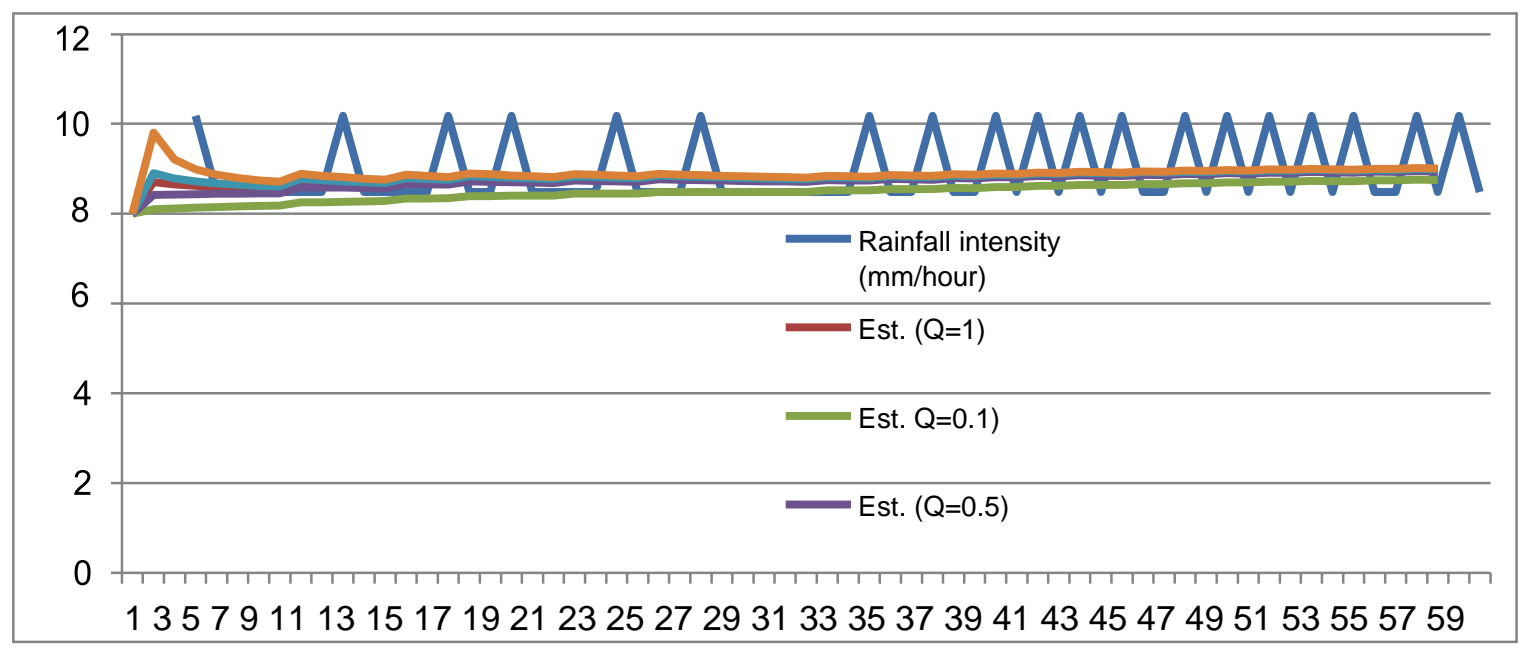

Figure 5. Comparison chart on data 3

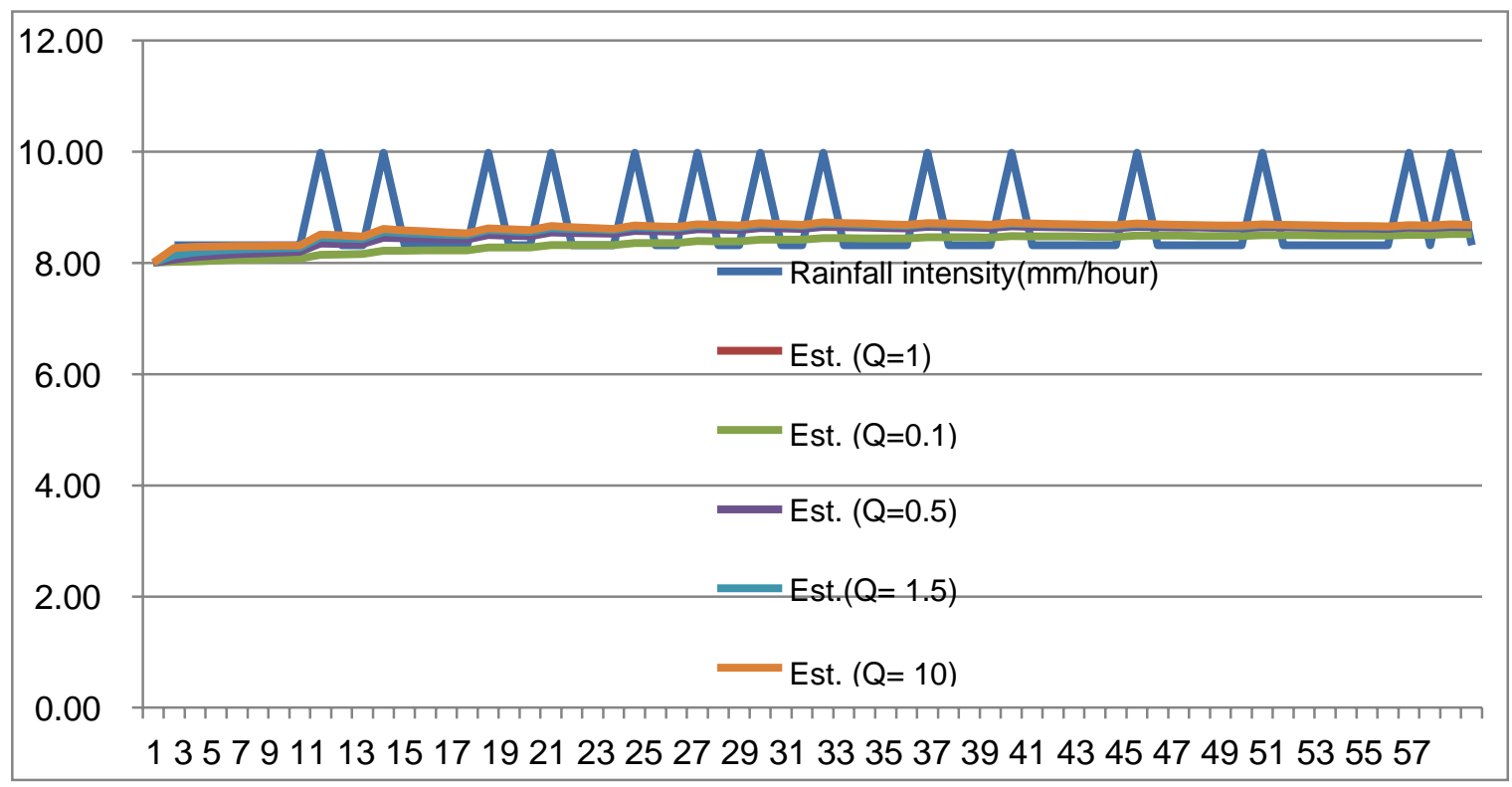

Figure 6. Comparison chart on data 4 


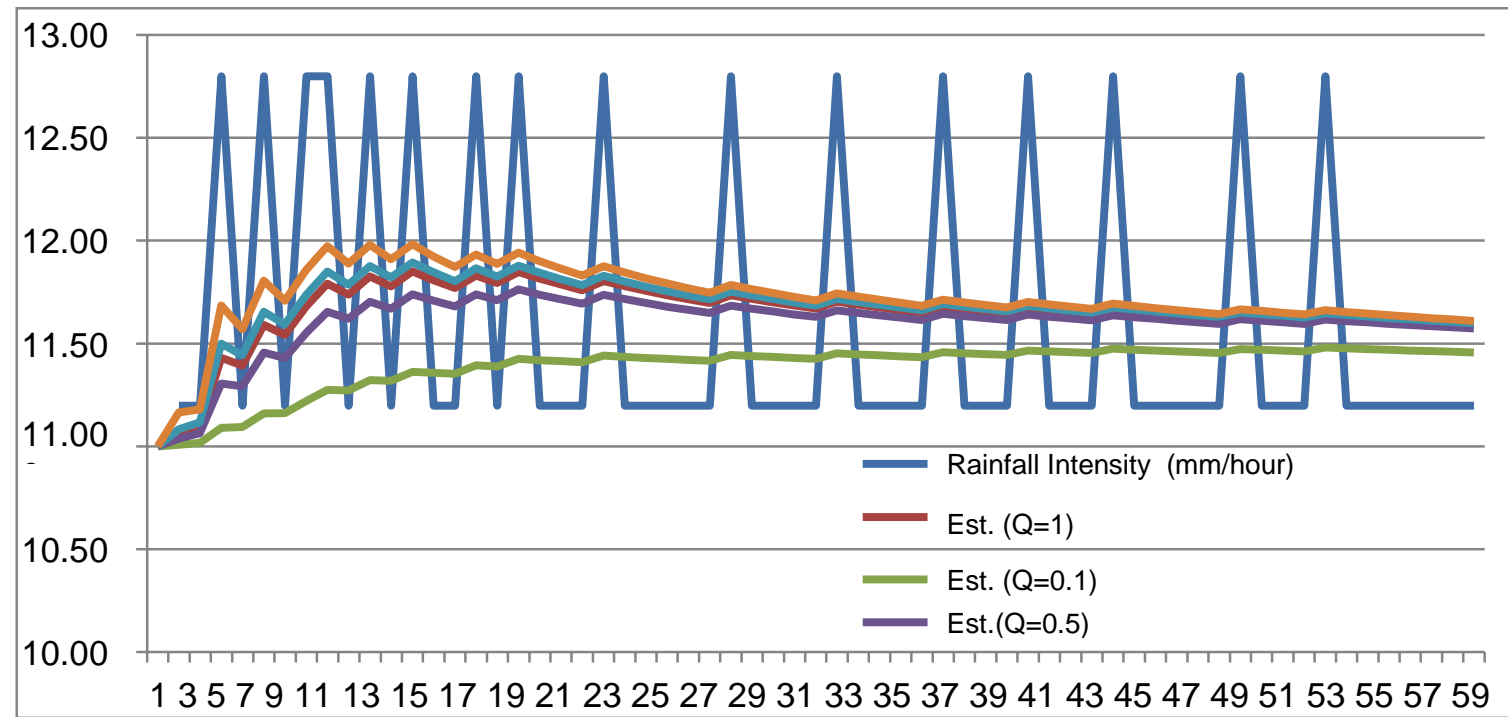

Figure 7. Comparison chart on data 5

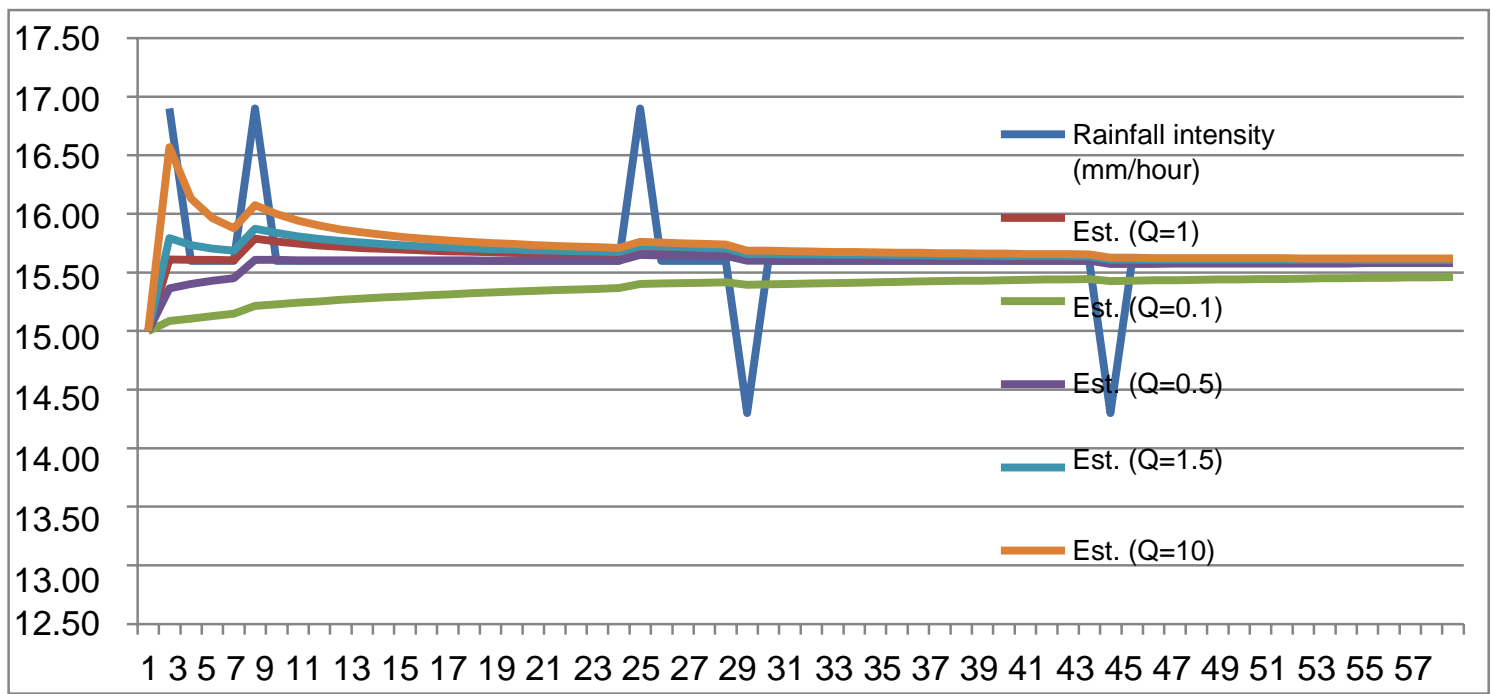

Figure 8. Comparison chart on data 6

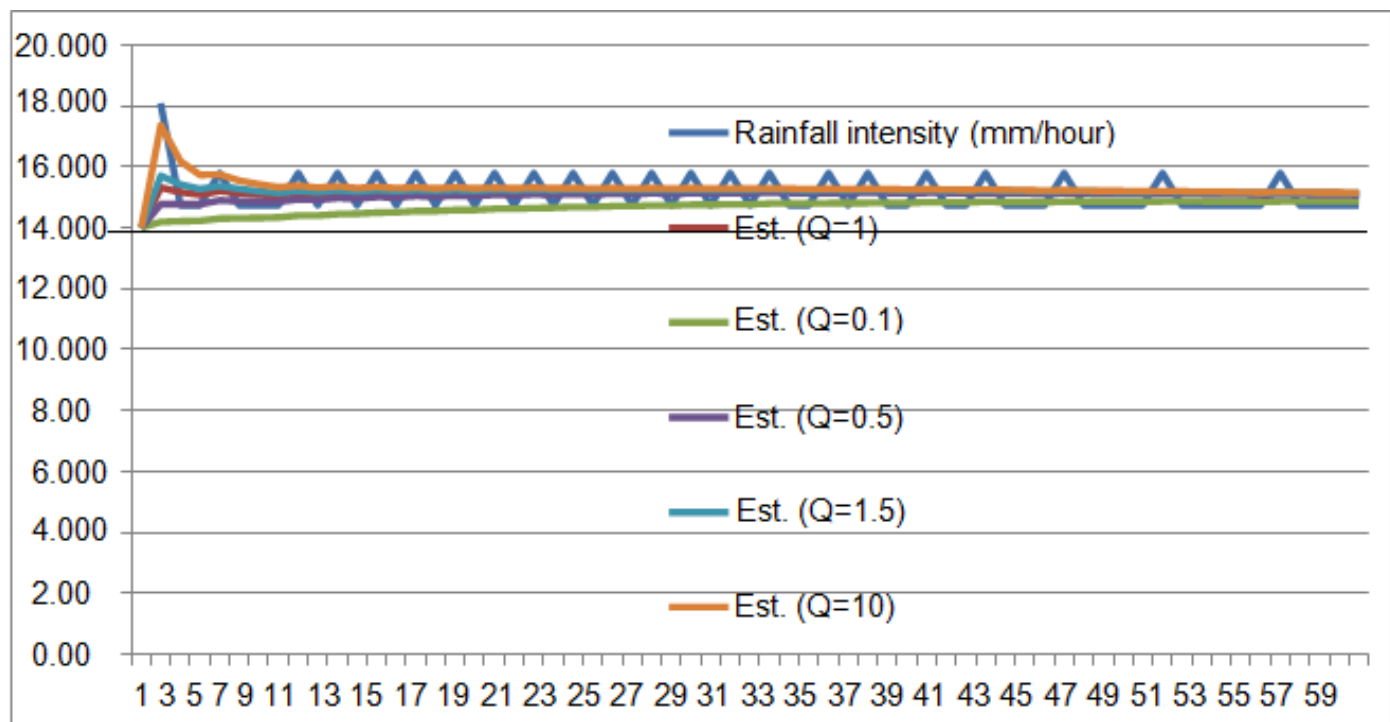

Figure 9. Comparison chart on data 7 


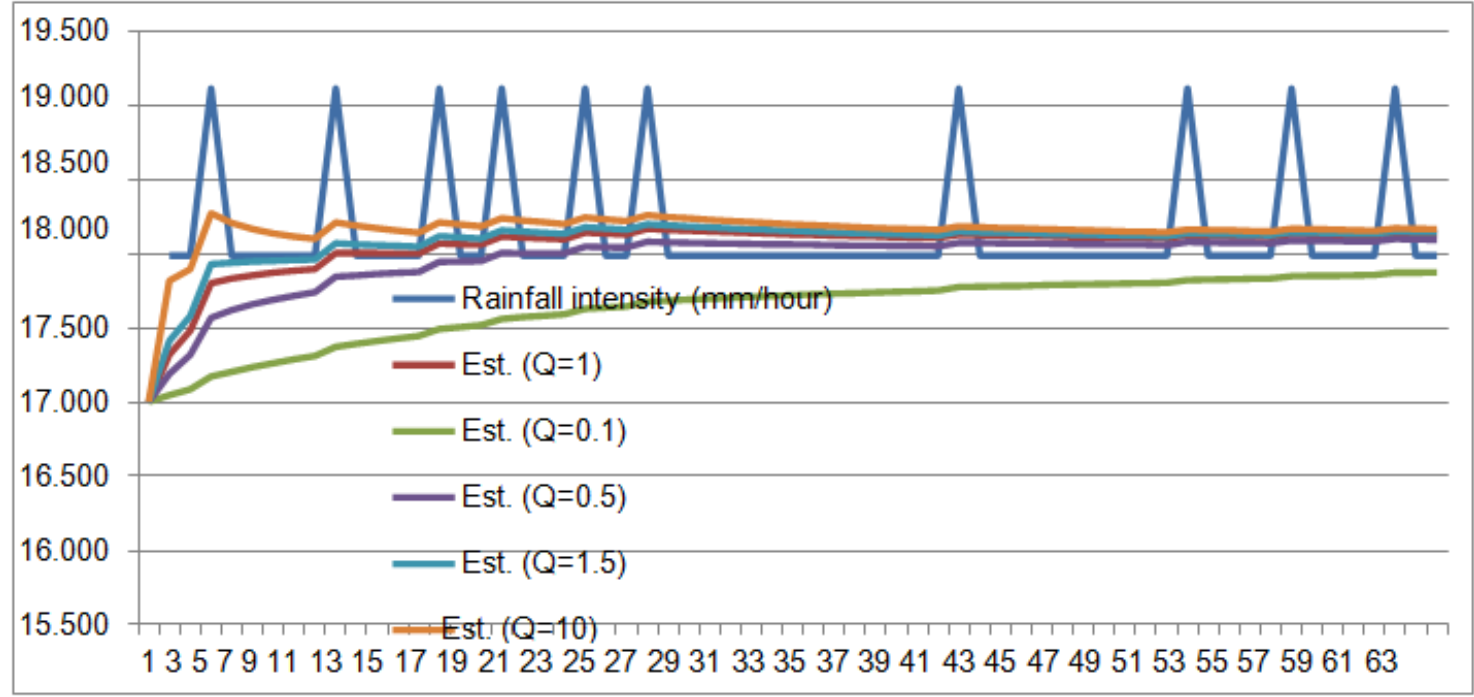

Figure 10. Comparison chart on data 8

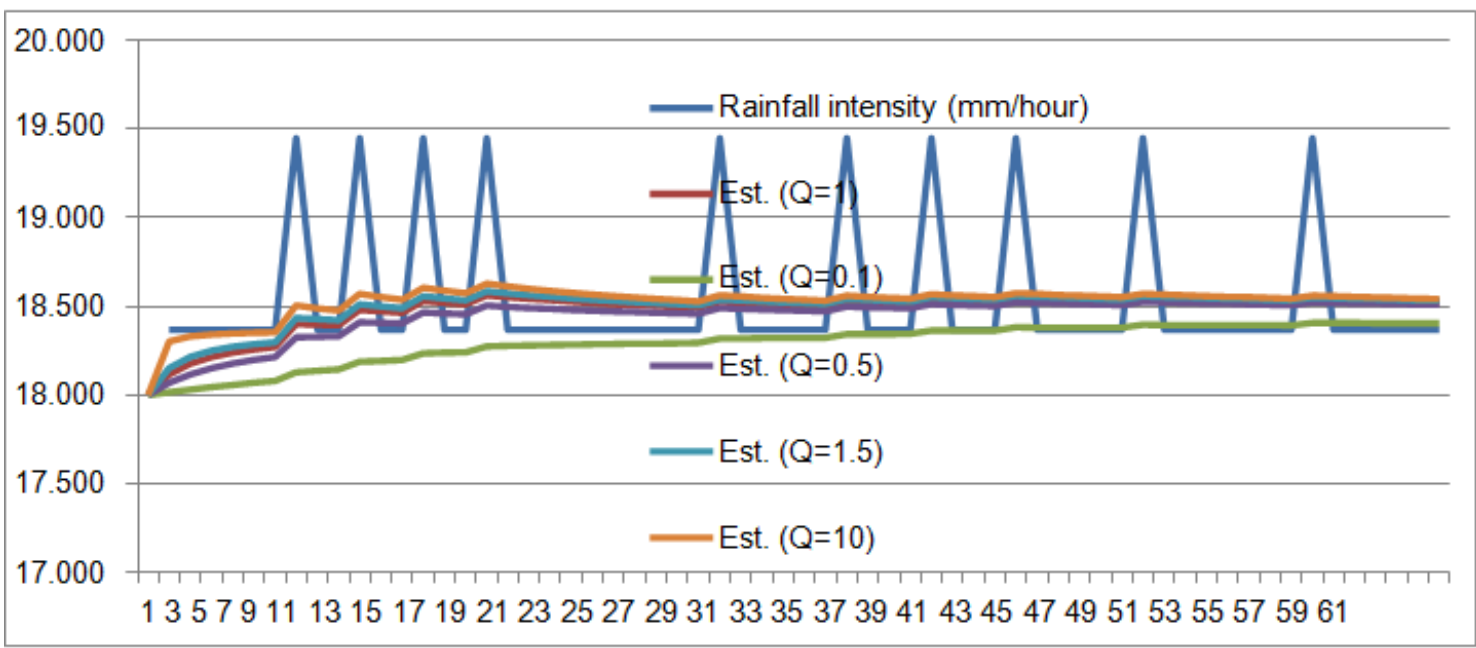

Figure 11. Comparison chart on data 9

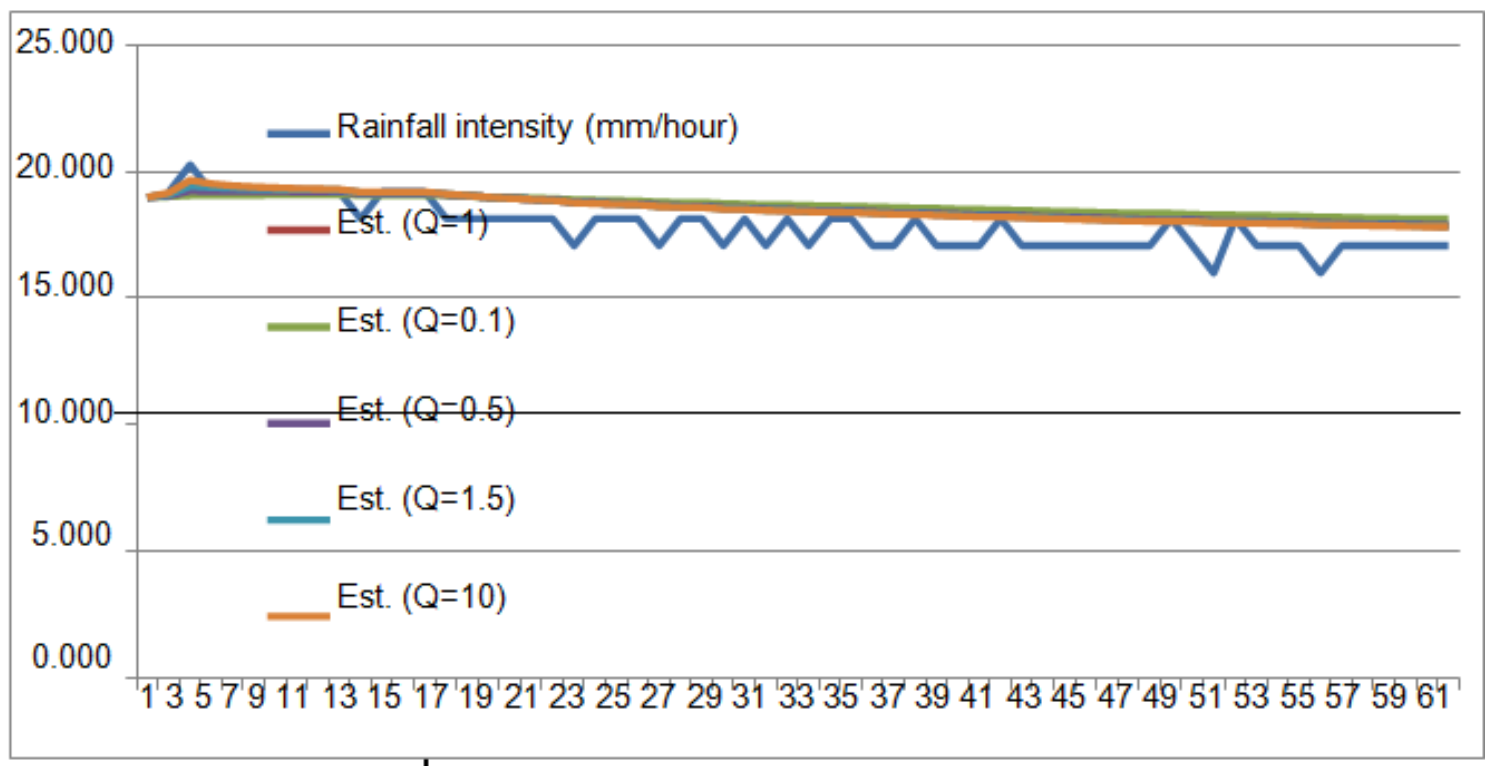

Figure 12. Comparison chart on data 10 
The flow-meter output signal from the rainfall intensity formulation can be estimated using the Kalman filter method. Comparison in Figure 12 can be seen that the parameter of the uncertainty process value is stable at a variation of the value 1 . This can occur because the variation in this value is a half-value variant of the measurement error.

\section{Conclusion}

The flow-meter signal can be used to calculate the value of the rainfall and is estimated using the Kalman filter method. By using the Kalman filter, where the uncertainty process value is varied, the estimated value is different. The stability of the flow-meter can be seen from the calman gain value and the smaller estimated error value. This shows that the measurement value is stable and accurate. Then the relationship between the flow-meter output signal and the rainfall intensity is seen by formulating the water discharge from the flow-meter to calculate the amount of rainfall intensity which will then be estimated to see its stability.

\section{REFERENCES}

[1] M. Syahbeni, A. Budiman, R. Syelly, I. Laksmana and Hendra, "Rancang Bangun Pendeteksi Curah Hujan Menggunakan Tipping Bucket Rain Sensor dan Arduino Uno," Agroteknika, vol. 1, no. 2, pp. 51-62, 2018.

[2] V. V. Kalchikhin and A. A. Kobzev, "Use of an Optical Rain Gauge in a System of Monitoring Severe weather Phenomena," IOP Conference Series: Earth and Environmental Science, vol. 211, pp. 012063, 2018.

[3] M. Y. Mustar and R. O. Wiyagi, "Implementasi Sistem Monitoring Deteksi Hujan dan Suhu Berbasis Sensor Secara Real Time," JURNAL ILMIAH SEMESTA TEKNIKA, vol. 20, no. 1, pp. 20-28, 2017.

[4] A. Ghurri, S. P. G. G. Tista, Syamsudin, "Pengujian Orifice Flow-meter dengan Kapasitas Aliran Rendah," Jurnal Mechanical, vol. 7, no. 2, pp. 61-66, 2016.

[5] V. Firmansyah, "Aplikasi Kalman Filter Pada Pembacaan Sensor Suhu Untuk Pemantauan Kondisi Ruangan Laboratorium," Jurnal Material dan Energi Indonesia, vol. 8, no. 1, pp. 1-7, 2018.

[6] B. H. Sirenden, "Data Fusion Method Based on Adaptive Kalman Filtering," Makara J. Technol. vol. 23, no. 1, pp. 39-47, 2019.

[7] S. Haykin, Signals and Systems. Singapore: Wiley. 2004.

[8] A. Hibatullah, "Smart Aquarium Berbasis IoT," Undergraduate thesis, Universitas Muhammadiyah Surakarta, Surakarta, 2019.

[9] A. Kadir, From Zero to a Pro Arduino, Yogyakarta: Penerbit Andi, 2018.

[10] F. Sirait, F. Supegina and I. S. Herwiansya, "Peningkatan Efesiensi Sistem Pendistribusian Air dengan Menggunakan IoT (Internet of Things)," Jurnal Teknologi Elektro, Universitas Mercu Buana, vol. 8, no. 3, 234-239, 2017. 